\title{
FEATURES OF THE DEMOGRAPHIC STRUCTURE AND THE CONDITION OF POPULATIONS OF THE RARE RELIC HEDYSARUM GMELINII LEDEB. (FABACEAE) IN PERIPHERAL AND CENTRAL PARTS OF ITS DISTRIBUTION RANGE
}

\author{
Larisa M. Abramova $^{1, \#}$, Valentina N. Ilyina ${ }^{2}$, Anna E. Mitroshenkova ${ }^{2}$, Alfia N. Mustafina ${ }^{1}$, \\ and Zinnur H. Shigapov ${ }^{1}$

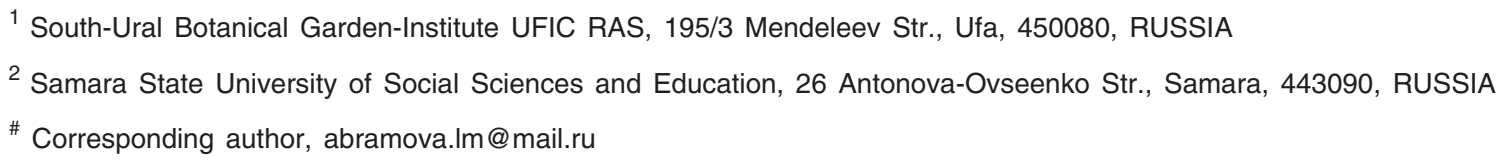

Communicated by Isaak Rashal

The features of the ontogenetic structure of cenopopulations of a rare species Hedysarum gmelinii Ledeb. (Fabaceae) were studied on the periphery of its range (the Middle Volga region and the Bashkir Cis-Urals) and in its central part (the Altai Mountains region). Types of cenopopulations were determined according to the "delta-omega" criterion: in the Bashkir Urals, they were mostly young, in the Middle Volga region, they were mature, in the Altai Mountains, they were maturing. The proportion of pregenerative individuals in populations increases in habitats with high moisture levels. Anthropogenic load (mainly in the form of grazing) had a greater effect on the number and density of individuals, rather than on the type of ontogenetic spectrum of cenopopulations.

Key words: Hedysarum gmelinii Ledeb., cenopopulation, ontogenetic spectrum, demographic indicators, habitat.

\section{INTRODUCTION}

At present, long-term and large-scale impact of anthropogenic load leads to degradation of ecosystems, catastrophic changes in their structural and functional organisation, impoverishment of flora and vegetation of unique natural complexes in different regions of the world. With increasing exploitation, rare plant species with a narrow ecological and phytocoenotic confinement have a greater risk of being lost from plant communities.

One of the most important and effective areas of modern biological science is the multidimensional study of rare plant species. Monitoring their populations is one of the methods of long-term and detailed research in the field of plant biology and ecology (Harper, 1960; 1970; 1977; Schemske, 1985; Zhukova, 2001; McCune and Grace, 2002; Rodriguez-Riaio et al., 2004; Abramova et al., 2010; 2011; 2014; Villellas et al., 2013; Dahlgren et al., 2017; Garnier et al.,
2018; Abramova et al., 2019 a; 2019b; Edelfeldt et al., 2019; Oldfather and Ackerly, 2019).

At the same time, phytocenotic, population and organismal levels of research are largely combined to obtain synthetic expression in modern biological and ecological studies. Population-ontogenetic methods make a great contribution to the study of biology and ecology of plants, as they provide information about reproductive activity, ontomorphogenesis, life history strategy, and resistance to anthropogenic factors. These methods allow to determine optimal conditions for the development of species and their cenopopulations in phytocoenoses and to identify the degree of tolerance and the main adaptation mechanisms of plants, manifested as a response to natural and anthropogenic impacts.

The problem of plant cover conservation is closely related to the biogeocenotic level of organisation of living systems 
(Smirnova et al., 2000; Lugovaya et al., 2013; Vaz et al., 2016; Smirnova and Geraskina, 2019). The development of protection measures to safeguard specific species of rare plants in regions and throughout the whole range is possible only with identifying and examining of most of its local populations.

A sufficient number of studies have been dedicated to the study of species biology and ecology at the organismal, population and cenotic levels of organisation (Smirnova et al, 2002; Basargin, 2007; Osmanova, 2008; 2016; Abramova et al., 2010; 2011; 2014; Osmanova, 2016; Karimova et al., 2017; Abramova et al., 2019 a; 2019b). In any case, the object of study is not a single plant, but a cenotic population of plants. A plant cenopopulation includes all individuals of a species within the same plant community. Its size and boundaries are determined by the boundaries of this phytocenosis.

The specific feature of plant cenotic populations, in contrast to animal populations, is that they are composed of sedentary forms. On the one hand, this leads to a relatively clear spatial demarcation of population elements that are easy to detect, but on the other hand, there are difficulties in separating intrapopulation units. In different scientific schools, both individuals of seed and vegetative origin (particule), clones (a set of individuals of vegetative origin) and even a part of an individual (phytometer, shoot, leaf, partial bush) can be viewed as structural units of a cenopopulation.

A detailed analysis of populations is used to determine biological features of plant species: analysis of spatial, ontogenetic, age structures, efficiency of seed production, etc.

The ontogenetic structure defines demographic indicators of populations, and both this structure and these indicators largely determine the viability of the population system (Zaugolnova and Smirnova, 1978), its self-recovery, selfmaintenance, stability and lability.

We study the structure populations of rare species and monitor these, in the Southern Urals and the Middle Volga region. The populations of rare species of flora, mainly related to endemic and relict representatives on the territory of these regions, act as model objects (Ilyina, 2006; 2007; 2011; Abramova et al., 2016; Ilyina, 2019).

The paper presents the results of many years of research on the ontogenetic structure and current condition of coenotic populations of the rare species of steppe and forest-steppe zones of the European part of Russia - Hedysarum gmelinii Ledeb. (Fabaceae) (Fig. 1). Cenopopulations of the species were studied from 2000 to 2019. A sample of collected data is provided in the article.

Hedysarum gmelinii belongs to the group of Pleistocene relics of South Siberian origin, the main range of which covers a significant territory from the mountains of Central Asia to Yakutia and Mongolia (Knyazev, 2014). Isolated relic fragments of the species range are located in the Southern Urals and the Middle Volga.

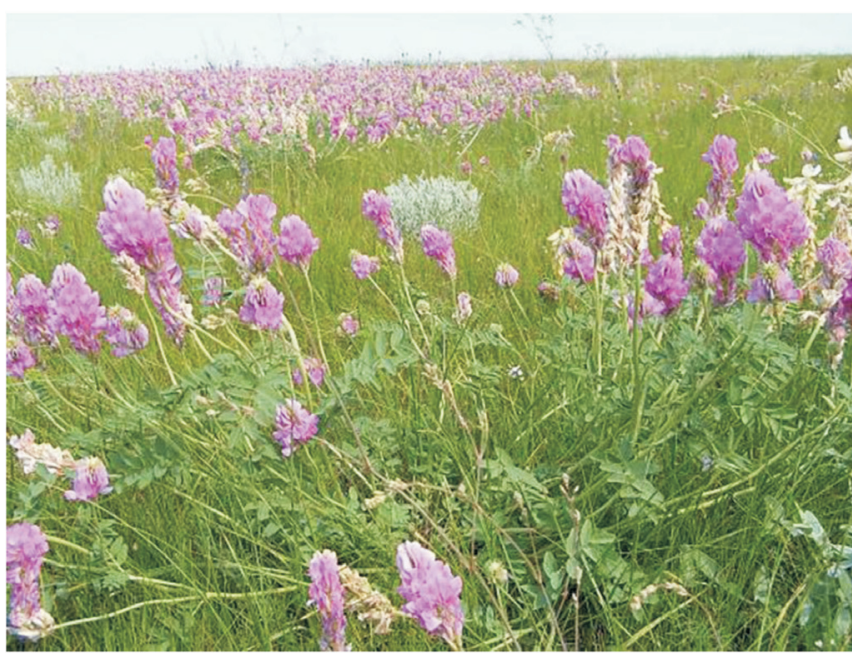

Fig. 1. Hedysarum gmelinii Ledeb.

Studies of $H$. gmelinii in various parts of the range are important for identifying differences and/or patterns of the population structure and some other parameters (Ilyina, 2006; Zhmud, 2014; Karnaukhova and Syeva, 2017; Ilyina, 2019; Syeva, Karnaukhova, 2019). Taking into account that this representative of legumes has a disjunct range and populations in the Southern Urals and the Middle Volga region are located in a land fragment torn from its main range, it is without a doubt a topical issue to study these populations and compare them with populations in the main (South Siberian) part of its spread area.

The purpose of the study was to study and compare the population indicators of $H$. gmelinii on the periphery of its range (European part) and in its central (Asian) part.

\section{MATERIALS AND METHODS}

H. gmelinii is a herbaceous taproot perennial up to $60 \mathrm{~cm}$ tall. The stems are ascending or erect, ribbed. Leaves are unparipinnate, with 5-11 elliptic leaflets. Flowers are located in the bosoms of the bracts and are collected in thick brushes (up to 40 flowers). Corolla is pink or pink-purple. Colouring may differ depending on the substratum: on chalk, it is closer to fawn, on limestone - to pink. The fruit is a 2-6 membered legume. It is confined to stony and limestone slopes of valleys and ravines with underdeveloped rubbly chernozems. This species is a mesoxerophyte, heliophyte, and calciphyte. It is included in the Red Books of Samara Oblast (Anonymous, 2017b), Chelyabinsk Oblast (Anonymous, 2017a), the Republic of Tatarstan (Anonymous, 2016), etc. and included in the IUCN Red List (Anonymous, 2004). Earlier it was protected in the Republic of Bashkortostan (Kucherov et al., 2001); currently it is excluded from the latest edition of the regional Red Book (Anonymous, 2011) as a stable species that does not require special measures for further conservation. At present, it is included in the list of plant world objects of Bashkortostan that need special attention and control in the natural environment and monitoring (Kucherov et al., 2001). 
The studies were conducted: 1) in forest-steppe and steppe zones of the Middle Volga region (on the territories of Samara Oblast (SO) and Orenburg Oblast (OrO)). The bank of the Volga River was explored in the vicinity of Klimovka Village in the Pre-Volga region. In the High Trans-Volga region, the Samara and Sok river basins (with the Kondurcha River tributary) were investigated in territories of Samara and Orenburg Oblast; the southern part of the Samara River catchment and part of the Bolshoy Irgiz River basin were explored in the Syrt Trans-Volga region within the administrative borders of the same regions; 2) in the forest-steppe zone of the Bashkir Pre-Ural (the Republic of Bashkortostan (RB)), in territories of Davlekanovsky, Alsheyevsky and Miyakinsky districts where the main populations of the species are located, which belong to the Bugulma-Belebey Upland (southern forest-steppe) and also includes a number of single domed peaks - shihans, some of which serve as habitats for this species; 3 ) in southern $\mathrm{Si}$ beria in the territory of the mountainous part of Altai (the Altai Republic (AR)), where the model species is quite widespread. Hedysarum gmelinii was studied on steppe slopes of the Chuya and Kansk accumulative basins (Ilyina, 2007).

Stony steppes occupy a prominent place in vegetation cover composition of the Middle Volga and Pre-Ural regions. They are located on the Zhiguli and Sengiley mountains in the Pre-Volga region. In the Trans-Volga and Pre-Ural regions, they are mainly confined to the spurs of the Bugulma-Belebey Upland and Obshchy Syrt where watersheds and slopes of large and small rivers are formed by bed rocks of Permian, Jurassic and less commonly Cretaceous periods. Above them, there are quaternary sediments that serve as a base for the formed soil horizons. The soils in this area are typical carbonate and residual-carbonate chernozems, sometimes washed away up to its parent rock. The climate is continental, with total annual precipitation of 400-600 mm.

The steppe zone is absent in Central Altai: only belts of steppe vegetation can be distinguished there in direction from lower tree lines to river valleys. There are various kinds of these vegetation belts - stony, solonchak, psamophytic. The climate of the Altai Mountains region is continental. The moisture is mostly distributed unevenly - from $200-300 \mathrm{~mm}$ in the southeast of the region to $2500 \mathrm{~mm}$ on the Katun ridge. Isolated basins are characterised by considerable dryness.

In order to study the biology of a species, it is necessary to observe the duration of complete ontogenesis as the total lifetime of individuals in all ontogenetic states.

Samples of 30-50 monitored $1 \mathrm{~m}^{2}$ transect areas were used to estimate age structure of $H$. gmelinii cenopopulations (CP). The following age states were considered when determining ontogenetic structure of $\mathrm{CP}$ according to the standard criteria (Rabotnov, 1950; Uranov and Smirnova, 1969; Harper and White, 1974; Rysin and Kazantseva, 1975; Sterk, 1975; Anonymous, 1976; Glotov, 1998; Nau- mova and Zlobin, 2009; Zlobin et al., 2013; Osmanova and Zhivotovsky, 2020): seedling (s), juvenile (j), immature (im), virginile $(\mathrm{v})$, young generative $\left(\mathrm{g}_{1}\right)$, mature generative $\left(\mathrm{g}_{2}\right)$, old generative $\left(\mathrm{g}_{3}\right)$, and subsenile (ss). The ontogenetic (age) spectrum of CP was created from the obtained data.

In order to highlight the ontogenetic states of a model species of plants it is necessary to determine qualitative indicators of a specific individual.

The ontogenesis of $H$. gmelinii was earlier described in our studies (Ilyina, 2006; 2011; 2019). Ontogenesis duration of individuals in the Middle Volga region is 11-46 or more years. According to other researchers, the duration of a long life cycle is about 50 years in southern Siberia (Karnaukhova and Syeva, 2017).

The ontogenetic structure of CPs was characterised using base demographic indicators: recovery index (Zhukova, 1995) and CP age index (Glotov, 1998). The state of CPs was estimated using the "delta-omega" criterion of Zhivotovsky (2001); it was used to determine which of the following types a particular $\mathrm{CP}$ belongs to: young, maturing, mature, transitional, aging, or old.

The main indicators of the dynamics of ontogenetic structure of plant species populations are the replacement index (I replacement), recovery index (I recovery), age index $(\Delta)$, and index efficiency $(\omega)$, which are calculated by formulas $(1-4)$ :

I replacement $=\mathrm{j}+\mathrm{im}+\mathrm{v} / \mathrm{g} 1+\mathrm{g} 2+\mathrm{g} 3+\mathrm{ss}+\mathrm{s}$

$\mathrm{I}$ recovery $=\mathrm{j}+\mathrm{im}+\mathrm{v} / \mathrm{g} 1+\mathrm{g} 2+\mathrm{g} 3$

$\Delta=\frac{\Sigma K_{i}+W_{i}}{\Sigma K} \times 100 \%$

where $K_{i}$ - size of the ontogenetic group; $W_{i}$ - scoring of the ontogenetic group; $K-$ size of the cenopopulation.

$\omega=\Sigma\left(N p-s s^{*} E p-s s\right) / N$

where $\mathrm{Np}$-ss - the number of individuals of a certain ontogenetic group, Ep-ss - the age coefficient, $N$ - the total number of individuals in the population.

The age index allows to estimate the ontogenetic level of a cenopopulation at a certain moment. It varies from 0 to 1 , with a higher value representing an older population.

The age coefficient for ontogenetic states is: $\mathrm{p}-0.0067 ; \mathrm{j}-$ 0.0180 ; im - 0.0474; v - 0.1192; g1 - 0.27; g2 - 0.5; g3 0.7310 ; ss -0.8808 ; and $\mathrm{s}-0.9819$.

Statistical data analysis was performed using default indicators with the MS Excel 2010 software package (Zaitsev, 1990; Fardeeva et al., 2009).

\section{RESULTS}

Four periods and ten ontogenetic conditions were allocated in the ontogenesis of Hedysarum gmelinii Ledeb. 
The latency period is represented by rounded seeds (se). Seed germination is epigeal (above-ground). Duration of this period is 1-3 years. A longer storage period of seeds leads to a sharp decrease of their germinating power.

The virginile period lasts from 1 year to 7 (9) years and includes four ontogenetic states.

In natural populations, seedlings (p) appear between April and May. They are up to 5-7 cm high; cotyledonous leaves are acuminate, the blade is $0.25-0.48 \mathrm{~cm}$ long and $0.2-0.37$ $\mathrm{cm}$ wide. Duration of the condition is $1-3$ months.

Juvenile (j) plants are up to 6-10 $\mathrm{cm}$ high, with simple leaves, blades up to $1.5 \mathrm{~cm}$ long and $0.6 \mathrm{~cm}$ wide, count of leaves is 3-6 (10) units. Duration of this condition is from 2 to 4 months.

Later, the plants enter the immature state (im). These are plants have $15 \mathrm{~cm}$ height, with 1-4-jugate leaves of transitional to mature type; leaflets are $1.3-2.5 \mathrm{~cm}$ long and $0.6-1.4 \mathrm{~cm}$ wide. Shoot branching can rarely be observed. Growth of shoots is monopodial. Duration of the condition is $1-2$ years.

Virginile (v) plants with an already formed habit characteristic of the given hedysarum reach up to $15-33 \mathrm{~cm}$ in height; their leaves are 4-8(10)-jugate, 14-32 cm long, up to 8-12 in total; leaflets $2.5-3.5 \mathrm{~cm}$ long, $1.5-2.3 \mathrm{~cm}$ wide. The root system is developed, taproot thickens, and its upper part lignifies. The duration of this condition is from 1 to 5 years.

The generative period may exceed 7-28 (45) years.

Young generative (g1) plants are up to $25-45 \mathrm{~cm}$ in height; they have 1-2 generative shoots with only 1-3 pedicels.
Radical leaves are 6-10-jugate, 12-20 cm long, up to 7-9 in number; 2-3 leaves 5-7 cm long are formed on shoots; the length of the blade is $1.4-3.5 \mathrm{~cm}$, and the width is $1.0-2.4$ $\mathrm{cm}$. Thickening of the root and basal part of the stem is noted. The small caudex carries perennating buds and parts of withered leaves. Duration of this condition is from 1 year to 6 (10) years.

The transition to a mature generative state (g2) occurs for 3-5 years of life. Mature generative individuals of $H$. gmelinii are $50-75 \mathrm{~cm}$ high, have $2-8$ shoots, most of them generative, and the total number of pedicels on them is 6-14. A powerful caudex is formed. The duration of this period is 4-12 (20) years

Old generative (g3) individuals have reduced reproductive activity. The height of plants is $25-50 \mathrm{~cm}$, they have 2-3 shoots, and the number of pedicels is reduced to $3-4$. The caudex is in the phase of particular dissection. The duration of the state is from 2 to 10 (15) years.

In the senile period, aging of individuals and loss of generative function is observed. Duration of this period in $H$. gmelinii probably reaches ten years.

Subsenile (ss) plants, up to $30-35 \mathrm{~cm}$ high, accumulate withered remains. The caudex is usually divided into 2-4 particulas, and the phase of taproot dissection is noted. The duration of this period is 4-8 years.

Senile (s) individuals are not numerous in populations. Underground parts of the plants are rapidly destroyed. Duration of the condition is less than 1 year.

Brief characteristics of $H$. gmelinii $\mathrm{CP}$ habitat in the aforenamed regions ( $\mathrm{SO}, \mathrm{OrO}, \mathrm{RB}, \mathrm{AR})$ are given in Tables 1

Table 1. Ecological and phytocenotic conditions of the habitats of the H. gmelinii cenopopulations in the European part of the range

\begin{tabular}{|c|c|c|c|c|c|}
\hline $\begin{array}{l}\text { No. } \\
\text { CPs }\end{array}$ & Locality & CPs position on the terrain & Parent rocks & $\begin{array}{c}\text { Anthropogenic load } \\
\text { levels }\end{array}$ & $\begin{array}{l}\text { Anthropogenic load } \\
\text { types }\end{array}$ \\
\hline 1 & RB, Burangulovo Village & Lower western slope, $20^{\circ}$ & sandstone & low & grazing, recreation \\
\hline 2 & RB, Tashtube Mount & Lower northwest slope, $20^{\circ}$ & sandstone & low & grazing \\
\hline 3 & RB, Alyshevo Village & Western slope, $5-10^{\circ}$ & sandstone & moderate & grazing \\
\hline 4 & RB, Pikarskaya Mount & Upper west slope, $5-10^{\circ}$ & sandstone & moderate & grazing \\
\hline 5 & RB, Satyrtau Mount & Lower eastern slope, $20-25^{\circ}$ & sandstone & moderate & grazing, recreation \\
\hline 6 & RB, Chyatay-Burzyan Village & Top of the southeast slope, $10-15^{\circ}$ & sandstone & moderate & grazing \\
\hline 7 & SO, Uspenskaya Mount & Middle part of the southern slope, $10^{\circ}$ & marl & moderate & grazing, recreation \\
\hline 8 & SO, Chelno-Vershiny Village & Middle part of southwest slope, $10-15^{\circ}$ & marl & moderate & grazing, recreation \\
\hline 9 & SO, Chelno-Vershiny Village & Middle part of the eastern slope, $10^{\circ}$ & marl & moderate & grazing, recreation \\
\hline 10 & SO, Sernovodsky Shihan & Middle part of the southeast slope, $15-20^{\circ}$ & marl & high & grazing, recreation \\
\hline 11 & SO, Guryev Ravine & Top of the southeast slope, $10-15^{\circ}$ & chalk & low & recreation \\
\hline 13 & OrO, the origins of the River Big Kinel & Middle part of the southeast slope, $10^{\circ}$ & sandstone & moderate & grazing \\
\hline 14 & OrO, the origins of the River Big Kinel & Middle part of the south slope, $10^{\circ}$ & sandstone & moderate & grazing \\
\hline 15 & OrO, Alyabyevo Village & Top of the southeast slope, $10-15^{\circ}$ & sandstone & moderate & grazing \\
\hline 16 & OrO, Alyabyevo Village & Top of the southwest slope, $10-15^{\circ}$ & sandstone & moderate & grazing \\
\hline 17 & OrO, Alyabyevo Village & Middle part of the southern slope, $10^{\circ}$ & sandstone & moderate & grazing \\
\hline
\end{tabular}

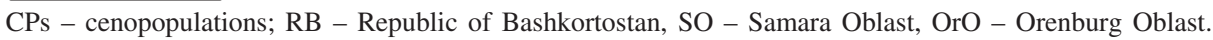


Table 2. Ecological and phytocenotic conditions of H. gmelinii CPs habitat in the southern Siberian part of the range

\begin{tabular}{|c|c|c|c|c|c|}
\hline $\begin{array}{l}\text { No. } \\
\text { CPs }\end{array}$ & Locality & CPs position on the terrain & Parent rocks & $\begin{array}{c}\text { Anthropogenic load } \\
\text { levels }\end{array}$ & $\begin{array}{l}\text { Anthropogenic load } \\
\text { types }\end{array}$ \\
\hline 18 & $\begin{array}{l}\text { AR, right bank of the Chuya River, } \\
\text { Chibit village }\end{array}$ & Lower part of the southern slope, $3-5^{\circ}$ & granite & high & grazing \\
\hline 19 & AR, Aktash Village & Lower part of the southern slope, $3-5^{\circ}$ & granite & high & grazing \\
\hline 20 & $\begin{array}{l}\text { AR, left bank of the Chuya River, } \\
\text { Chibit Village }\end{array}$ & Lower part of the western slope, $5^{\circ}$ & granite & moderate & grazing \\
\hline 22 & AR, Ongudai Village & Lower part of the southern slope, $5^{\circ}$ & granite & low & grazing \\
\hline
\end{tabular}

CPs - cenopopulations; AR - Altai Republic.

and 2. CPs were named after the settlement or natural feature closest to it.

Species populations of the European part of the range are located on southern exposure slopes and proximate to it with a slope of $5-35^{\circ}$, mainly being $10-15^{\circ}$; the majority of its habitats are disturbed by recreation or grazing to a lesser or higher degree. Communities including Hedysarum gmelinii Ledeb. are mostly located on middle or lower parts of slopes, less likely on hilltops, on sod soils with dense grass canopy (sometimes up to $80 \%$ ). H. gmelinii starts being codominant in phytocenoses on chalky soils of the Samara Pre-Volga region (Guriev Ravine); soils are eroded in this region, quite often represented by rendzine soils, with total projective cover of grass canopy being less than $30 \%$.

The studied Altaic H. gmelinii CPs were more likely to be located on lower parts of slopes of southern and western exposures with lesser slope (about $3-5^{\circ}$ ); state of disturbance of soil-vegetable cover as a result of grazing varied depending on how far the territory is located from settlements. Anthropogenic loads affect the number of individuals in CP in the territory of the AR: under overgazing, the number of specimens is low; populations form aggregations of plants with large gaps between clusters. H. gmelinii was codominant specimen only in one of studied sites (CP No. 22) which had less grazing. Total projective cover of herb layer was $30-50 \%$.

Total density, effective density and age composition of $H$. gmelinii populations are given in Table 3 . The contribution of plants of different age states to population density is weighted according to their energy efficiency (Zhivotovsky, 2001).

\section{DISCUSSION}

Total density of H. gmelinii CPs in the European part of the range varied from 1.7 to $13.6 \mathrm{ind} . / \mathrm{m}^{2}$, with effective density $1.5-9.2$ ind. $/ \mathrm{m}^{2}$. The generative fraction prevailed in the most of the populations. In the RB region, CP No. 1 and No. 5 had the maximum density values (12.2 ind. $\left./ \mathrm{m}^{2}\right)$, where the fraction of pregenerative individuals prevailed (69.7, 65.2\%, respectively). In the SO region, CP No. 7 and No. 9 were notable for having high density (with density of
12.7 and 13.6 ind. $/ \mathrm{m}^{2}$ ), although generative individuals prevailed there (70.7 and $70.9 \%$, respectively).

CPs had the total density of $3.8-19.6$ ind. $/ \mathrm{m}^{2}$ in the AR territory, with an effective density of $2.3-12.1$ ind. $/ \mathrm{m}^{2}$, which was significantly higher than values in the European part of Russia. Effective density of individuals in CP Nos. 18-22 was lower than total density, more than $30 \%$ on average.

No clear dependence of indicators of total and effective density from the degree of anthropogenic load of habitat was noted for CPs in the European part of the range: low load on CPs Nos. 1, 2, 11, 12 where total density of individuals was $1.7-12.2$ ind. $/ \mathrm{m}^{2}$, effective density - 1.6-6.9 ind.$/ \mathrm{m}^{2}$; medium load on CPs Nos. 3-9, 13-17 with $1.8-12.7$ and $1.5-9.2$ ind. $/ \mathrm{m}^{2}$; heavy load on CP No. 10 with 3.8 and 2.6 ind. $/ \mathrm{m}^{2}$, respectively. In the Asian part of the range, we have noted a decrease in these population characteristics under higher anthropogenic load (CPs No. 18 and No. 19 experienced a high anthropogenic load, where densities in CP no. 20 were medium, CPs No. 21 and No. 22 - low). This proves once again that the number of $\mathrm{CP}$ individuals decreases on the edge of species distribution even under moderate anthropogenic pressure and that edgeareal CPs of relict species require protection.

The study of the ontogenetic structure of $H$. gmelinii CPs showed a rather high variety of types of ontogenetic spectra in the European part of the range and a more "even" composition of CPs in Asia.

In the $\mathrm{RB}$, the generative fraction prevailed in CPs Nos. 1, $2,3(73.9 \%, 97.6 \%$, and $81.8 \%$, respectively), where the values of the total and effective density were the closest $\left(2.1,2.8 ; 1.6,1.7\right.$ and $\left.1.5,1.8 \mathrm{ind} . / \mathrm{m}^{2}\right)$. The preregenerative fraction size was maximum in CPs Nos. 1, 5, and 6, where the differences in terms of density were the most pronounced. The majority of postgenerative individuals were found in CP No. 2 (2.4\%), where the pregenerative fraction was entirely absent. At the time of the conducted studies, generative plants prevailed (48.5-72.3\%) in all CPs in territories of SO and OrO. CP No. 10 had the closest indicators of total and effective density (3.8 and $2.6 \%$, respectively), but at the same time it had the lowest minimal density among CPs in the Samara Trans-Volga region. 
Table 3. Density and age composition of cenopopulations of $\mathrm{H}$. gmelinii

\begin{tabular}{|c|c|c|c|c|c|c|c|c|c|c|}
\hline $\begin{array}{l}\text { No. } \\
\text { CPs }\end{array}$ & $\begin{array}{c}\text { Effective density, } \\
\text { ind. } / \mathrm{m}^{2}\end{array}$ & $\begin{array}{l}\text { Density, } \\
\text { ind. } / \mathrm{m}^{2}\end{array}$ & $\mathrm{p}$ & $\mathrm{j}$ & $\mathrm{im}$ & $\mathrm{v}$ & $\mathrm{g}_{1}$ & $\mathrm{~g}_{2}$ & $\mathrm{~g}_{3}$ & ss \\
\hline 1 & 4.6 & 12.2 & 14.5 & 30.6 & 13.2 & 11.5 & 4.3 & 20.4 & 4.3 & 1.3 \\
\hline 2 & 1.6 & 1.7 & 0.0 & 0.0 & 0.0 & 0.0 & 2.4 & 88.1 & 7.1 & 2.4 \\
\hline 3 & 1.5 & 1.8 & 0.0 & 4.5 & 0.0 & 13.6 & 13.6 & 68.2 & 0.0 & 0.0 \\
\hline 4 & 2.8 & 6.1 & 30.1 & 13.7 & 9.2 & 4.6 & 1.3 & 32.0 & 7.8 & 1.3 \\
\hline 5 & 4.5 & 12.2 & 48.9 & 6.2 & 4.6 & 5.6 & 7.2 & 23.3 & 4.3 & 0.0 \\
\hline 6 & 4.2 & 10.0 & 11.6 & 27.3 & 20.1 & 7.6 & 2.8 & 29.7 & 0.8 & 0.0 \\
\hline 7 & 8.6 & 12.7 & 5.0 & 6.4 & 8.4 & 9.5 & 17.3 & 28.6 & 24,8 & 0.0 \\
\hline 8 & 8.1 & 10.5 & 3.1 & 2.8 & 5.4 & 2.9 & 13.5 & 42.1 & 25.9 & 4.3 \\
\hline 9 & 9.2 & 13.6 & 4.4 & 3.2 & 8.1 & 8.3 & 16.2 & 22.1 & 32.6 & 5.1 \\
\hline 10 & 2.6 & 3.8 & 5.2 & 5.4 & 10.6 & 10.6 & 13.8 & 41.6 & 12.8 & 0.0 \\
\hline 11 & 6.9 & 9.7 & 3.3 & 6.8 & 2.7 & 12.4 & 16.5 & 30.1 & 25.7 & 2.5 \\
\hline 13 & 4.5 & 6.5 & 8.5 & 0.0 & 6.8 & 12.4 & 20.1 & 26.4 & 25.8 & 0.0 \\
\hline 14 & 6.3 & 9.5 & 13.7 & 4.2 & 5.3 & 11.6 & 12.4 & 39.1 & 13.7 & 0.0 \\
\hline 15 & 5.1 & 7.2 & 5.8 & 6.4 & 3.4 & 12.6 & 17.5 & 35.1 & 18.5 & 1.7 \\
\hline 16 & 6.5 & 11.8 & 6.4 & 2.8 & 12.4 & 26.5 & 25.0 & 8.8 & 14.7 & 3.4 \\
\hline 17 & 6.0 & 8.5 & 1.5 & 3.6 & 8.4 & 9.1 & 13.6 & 26.3 & 32.0 & 5.5 \\
\hline 18 & 2.3 & 3.8 & 3.6 & 7.5 & 10.6 & 19.4 & 17.2 & 15.8 & 15.8 & 2.7 \\
\hline 19 & 3.3 & 5.4 & 5.8 & 2.7 & 13.1 & 17.9 & 15.6 & 18.4 & 18.4 & 3.0 \\
\hline 20 & 8.2 & 12.4 & 6.7 & 6.7 & 9.1 & 10.5 & 17.5 & 18.5 & 18.5 & 0.5 \\
\hline 21 & 9.5 & 15.6 & 6.4 & 7.4 & 3.9 & 25.4 & 15.8 & 15.4 & 15.4 & 2.1 \\
\hline 22 & 12.1 & 19.6 & 3.5 & 6.2 & 10.2 & 19.3 & 15.5 & 13.5 & 13.5 & 5.5 \\
\hline
\end{tabular}

CPs - cenopopulations; $\mathrm{p}$ - seedling, $\mathrm{j}$ - juvenile, im - immature, $\mathrm{v}$ - virginile, $\mathrm{g}_{1}$ - young generative, $\mathrm{g}_{2}$ - mature generative, $\mathrm{g}_{3}$ - old generative, ss subsenile; cenopopulations numbers correspond to Tables 1 and 2.

In the examined $\mathrm{CPs}$ in $\mathrm{AR}$, the generative fraction of individuals predominated (55.3-66.5\%), however, the number of pregenerative individuals was also high (33.0-43.1\%). Post-generative individuals were recorded in all CPs (0.5-5.5\%, averaging about $2.7 \%$ ).

The distributions of individuals by ontogenetic groups and demographic indicators in $H$. gmelinii cenopopulations are given in Table 4.

"Delta-omega" classification of the studied cenopopulations of $H$. gmelinii showed that five CPs (Nos. 1, 4-6, 16) are young $(\Delta=0.18-0.29, \omega=0.37-0.55)$ in the European part of the range, where pregenerative individuals were the most represented (four of them were recorded in the Republic of Bashkortostan, one in the Orenburg Trans-Volga region). Six of the studied CPs were transitional (Nos. 7, 9, 10, 12-14) with demographic indicators of $\Delta=0.35-0.45, \omega=$ 0.66-0.68 (three in Samara Trans-Volga, one in Samara Pre-Volga, two in Orenburg Trans-Volga). Six model CPs (Nos. $2,3,8,11,15,17)$ were characterised as mature $(\Delta=$ $0.39-0.52, \omega=0.70-0.97)$ with high numbers of middle-aged generative individuals in its composition and a low amount of pregenerative individuals (two in the RB, two in the Orenburg Trans-Volga region, one in the Samara Pre-Volga region, one in the Samara Trans-Volga region).

In two CPs (Nos. 1 and 6), the recovery index was greater than one (1.91 and 1.65 , respectively) but the lowest in the rest of the CPs (0.22-0.99); the index was zero in CP No. 2, which indicated total absence of a generative fraction. The age index was very low (0.0-0.06), which indicated both poor replenishment by young individuals and intensive dieback of individuals at an old generative state.

In the Asian part of the range, four CPs (Nos. 18, 19, 21, 22) were characterised as maturing $(\Delta=0.33-0.35, \omega=$ $0.61-0.62)$, with a recovery index of $0.69-0.79$ and age index of $0.02-0.06$. One CP no. 20 was transitional $(\Delta=0.36$, $\omega=0.66$ ) with a recovery index of 0.50 and a minimum age index of 0.01 .

According to the Uranov and Smirnova classification (1969), the examined H. gmelinii CPs in the European part of the range were normal and most of them were incomplete-membered. The absence of subsenile and senile individuals in the spectra of a significant part of CPs was associated with a reduced course of ontogenesis due to plants that die rapidly at the old generative state. Individuals of $H$. gmelinii undergo complete ontogenesis only under favourable growing conditions, sufficiently high soil moisture and in the absence or under weak anthropogenic disturbances. All CPs present in the Asian part of the range were full-membered, which indicated more favourable living conditions, including minimal anthropogenic load.

The averaged ontogenetic spectrum of the studied $H$. gmelinii CPs for the entire territory and the spectra for each 
Table 4. Distribution of individuals by ontogenetic states and demographic indicators of the state of $H$. gmelinii cenopopulations

\begin{tabular}{|c|c|c|c|c|c|c|c|c|}
\hline \multirow[t]{2}{*}{ CPs } & \multicolumn{3}{|c|}{ Ontogenetic state, $\%$} & \multicolumn{5}{|c|}{ Demographic indicators } \\
\hline & $\mathrm{p}+\mathrm{j}+\mathrm{im}+\mathrm{v}$ & $g_{1}+g_{2}+g_{3}$ & ss & $\Delta$ & $\omega$ & $\begin{array}{l}\text { Cenopopulatio } \\
\text { ns type }\end{array}$ & recovery index & age index \\
\hline \multicolumn{9}{|c|}{ The European part of the range } \\
\hline 1 & 69.7 & 28.9 & 1.3 & 0.18 & 0.37 & young & 1.91 & 0.02 \\
\hline 5 & 65.2 & 34.8 & 0.0 & 0.18 & 0.37 & young & 0.47 & 0.00 \\
\hline 6 & 66.7 & 33.3 & 0.0 & 0.19 & 0.42 & young & 1.65 & 0.00 \\
\hline 4 & 57.5 & 41.2 & 1.3 & 0.25 & 0.45 & young & 0.67 & 0.02 \\
\hline 16 & 48.1 & 48.5 & 3.4 & 0.29 & 0.55 & young & 0.99 & 0.04 \\
\hline 14 & 34.8 & 65.2 & 0.0 & 0.35 & 0.66 & transitional & 0.53 & 0.00 \\
\hline 10 & 31.8 & 68.2 & 0.0 & 0.36 & 0.69 & transitional & 0.47 & 0.00 \\
\hline 7 & 29.3 & 70.7 & 0.0 & 0.39 & 0.68 & transitional & 0.41 & 0.00 \\
\hline 15 & 28.2 & 71.1 & 1.7 & 0.39 & 0.71 & mature & 0.40 & 0.02 \\
\hline 13 & 27.7 & 72.3 & 0.0 & 0.39 & 0.69 & transitional & 0.38 & 0.00 \\
\hline 11 & 25.2 & 72.3 & 2.5 & 0.42 & 0.71 & mature & 0.35 & 0.03 \\
\hline 9 & 24.0 & 70.9 & 5.1 & 0.45 & 0.68 & transitional & 0.34 & 0.05 \\
\hline 17 & 22.6 & 71.9 & 5.5 & 0.47 & 0.70 & mature & 0.31 & 0.06 \\
\hline 3 & 18.2 & 81.8 & 0.0 & 0.39 & 0.85 & mature & 0.22 & 0.00 \\
\hline 8 & 14.2 & 81.5 & $4, .3$ & 0.48 & 0.77 & mature & 0.17 & 0.04 \\
\hline 2 & 0.0 & 97.6 & $2, .4$ & 0.52 & 0.97 & mature & 0.0 & 0.02 \\
\hline \multicolumn{9}{|c|}{ Asian part of the range } \\
\hline 21 & 43.1 & 54.8 & 2,1 & 0.33 & 0.61 & maturing & 0.79 & 0.02 \\
\hline 18 & 41.1 & 56.2 & 2,7 & 0.33 & 0.61 & maturing & 0.73 & 0.03 \\
\hline 22 & 39.2 & 55.3 & 5,5 & 0.35 & 0.62 & maturing & 0.71 & 0.06 \\
\hline
\end{tabular}

CPs - cenopopulations; $\mathrm{p}$ - seedling, $\mathrm{j}$ - juvenile, im - immature, $\mathrm{v}$ - virginile, $\mathrm{g}_{1}$ - young generative, $\mathrm{g}_{2}$ - mature generative, $\mathrm{g}_{3}$ - old generative, ss subsenile; $\Delta-$ age index, $\omega$ - index efficiency of cenopopulation. Cenopopulations numbers correspond to Tables 1 and 2.

region are presented in Figure 2. Prevalence of mature generative individuals $(43.6 \%)$ was characteristic for populations in the RB, the maximum was registered for this part of the spectrum; local peaks appeared for early stages of ontogenesis (seedlings - $17.5 \%$, juvenile individuals $13.7 \%$ ). The remaining stages were represented by a significantly smaller proportion of individuals (immature - 7.7\%, virginile $-7.2 \%$, young generative $-5.3 \%$, old generative - $4.1 \%$, subsenile - $0.8 \%$ ).

In $\mathrm{SO}$ and $\mathrm{OrO}$, ontogenetic spectra were generally similar among each other but somewhat differerent from the Bashkir CPs. In the Middle Volga area, the spectrum of CPs was also characterised by predominance of mature generative individuals $(32.7 \%$ and $27.1 \%$, respectively), subdominance of old generative plants $(24.9 \%$ and $21.0 \%)$, and lower presence of individuals in the virginile period of ontogenesis.

The averaged ontogenetic spectrum of CPs in the European part of Russia was centred with a maximum on middle-aged generative individuals $(34.9 \%)$. The remaining ontogenetic groups had approximately the same proportion of individuals within $7-16 \%$ of the total number, with the exception of the subsenile stage $(1.7 \%)$.
The Altai group of CPs was characterized by predominance of the generative fraction of individuals $(58.1 \%)$, a rather

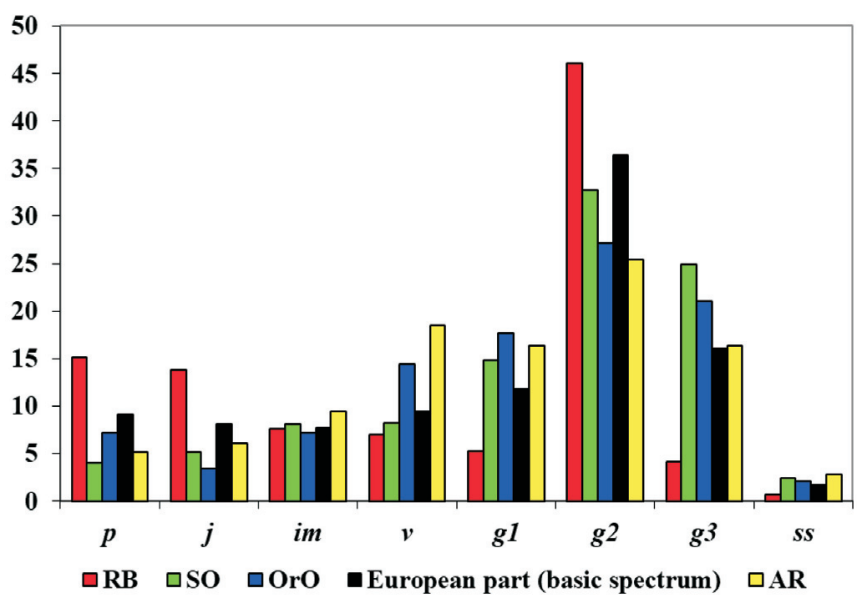

Fig. 2. Averaged (basic) ontogenetic spectrum of Hedysarum gmelinii cenopopulations. On the $\mathrm{x}$ axis: ontogenetic state: $\mathrm{p}$ - seedling, $\mathrm{j}$ - juvenile, im - immature, $\mathrm{v}$ - virginal, $\mathrm{g}_{1}$ - young generative, $\mathrm{g}_{2}$ - middle-aged generative, $\mathrm{g}_{3}$ - old generative, ss - sub-senile; along the y axis - the proportion of individuals of this ontogenetic state, \%. RB - Republic of Bashkortostan, SO - Samara Oblast, OrO - Orenburg Oblast, AR - Altai Republic. 
high content of pregenerative plants $(39.2 \%)$ and a low proportion of senile specimens (less than $3 \%$ ).

The species grows primarily in conditions favourable in terms of moisture and temperature, mostly on middle and lower parts of slopes with a dense herb layer, and according to our observations, especially the development of a sod layer determines the possibility of seed germination and the development of young plants. Each specific CP had its own age spectrum. This depends on habitat conditions, density of grass canopy, degree of anthropogenic load and fluctuations in weather conditions, which affect the characteristics of seed germination and rates of development of individuals in a particular ontogenetic state.

In our opinion, the differences in ontogenetic spectra are associated both with the ecological and phytocenotic conditions of the habitats and with the degree of anthropogenic load. With an increase in the impact of an anthropogenic factor and in a drier climate, the percentage of seed germination and seedling survival rate sharply decreases among $\mathrm{CPs}$; therefore, the spectra in SO and OrO are more rightskewed and CPs of the young type are rarely recorded.

The ontogenetic structure of specific natural $H$. gmelinii CPs had two major types of spectrum in the territory of the RB: left-skewed and centred. A left-skewed single-peak ontogenetic spectrum was formed in CP No. 1, where juvenile individuals accounted for the maximum (30.6\%). This population was located in a habitat disturbed by grazing, near a settlement where sparseness of the grass stand promoted seed germination and development of young individuals. In the remaining populations, a centred ontogenetic spectrum was formed with a maximum for middle-aged generative individuals (29.7-88.1\%). Individuals of the young fraction were represented minimally or completely absent. This was a result of poor seed germination and high density of communities in which the species grows; this was connected with higher elimination of seedlings and juvenile individuals in dry slope habitats as well. Centred spectra were characteristic of populations with a stable status in communities (Naumova and Zlobin, 2009).

The centred ontogenetic spectrum had two peaks in CPs Nos. 4 and 6. The first peak in CP 6 occurred for juvenile individuals $(27.3 \%)$ and in CP No. 4 for seedlings $(30.1 \%)$, the second peak was found for medium generative individuals (29.7 and $32.0 \%$, respectively). These populations were slightly disturbed by livestock grazing; they were located in the upper part of the mountain slope with a low percentage of projective soil cover by grass stands, which contributes to the rapid transition of young individuals to a generative state.

In the western part of the range, CPs were characterised by a shift in peaks of the ontogenetic spectrum to the right, this was especially pronounced in CP No. 9 (SO, near ChelnoVershiny Village). This locus is registered in one of the largest geographical populations in the Samara Trans-Volga region in the Kondurcha Ravine. A high density of individ- uals and significant development of a sod layer characterised this area. Seed germination was low due to accumulation of a steppe mat. The core of CPs was made up of generative individuals, i.e. the most long-lived.

In the AR territory, mature generative individuals predominated in all model CPs. Old generative plants (CPs Nos. 19, $20)$ as well as virginile individuals (CPs Nos. 18, 21, 22) accounted for the local peak of the ontogenetic spectrum. As mentioned earlier, the composition of ontogenetic groups in CPs of one region often varies insignificantly and the allocation of local peaks of spectra is often factitious, for example in CP 19: g2 - 23.5\%, g3 - 18.4\%; v - 17.9\%; g1 $15.6 \%$; im $-13.1 \%$.

Based on the data obtained, it can be assumed that the optimal living conditions for $H$. gmelinii are those in which the ontogenetic spectra of the CPs are close to the base spectrum. These are CPs 1 and 4 in RB that are located on middle or top parts of slopes with low anthropogenic load, in comparison with averaged spectrum of the region (RB). The CPs No. 7 and No. 12 in SO were found in the upper and middle parts of a slope with low or medium anthropogenic load. CPs No. 15 and No. 17 were located in upper and middle parts of slopes with medium anthropogenic load in OrO.

For comparison, we present our data on the ontogenetic structure of $H$. gmelinii $\mathrm{CP}$ in the Altai Mountains region, where the structure was full-membered left-modal and smoother as opposed to the "western" range, but still had two peaks. As in the first case, mature generative individuals predominated, although their percentage of the total was about $25 \%$. A prominent part was played by virginile plants, which accounted for the second maximum of spectrum - about $18.5 \%$. The total generativity of the Altai populations was about $58 \%$, which was lower by more than $10 \%$ compared to the Volga and Cis-Urals populations.

In general, the obtained data is in line with research results by Siberian scientists (Karnaukhova and Syeva, 2017), which indicate that the proportion of pregenerative plants rises with an increase in moisture of Hedysarum habitats this can be clearly noted in CPs in the territory of the Republic of Bashkortostan and the Altai Republic.

The generalised data indicates that ontogenetic spectra of CPs are rather highly diverse and that cenopopulations of the species as part of phytocenoses maintain lability under low and sometimes medium anthropogenic load. However, there is a similarity in the spectra of the Bashkir and Altai populations, which can be primarily associated with high moisture and the manifestation of mesophytic features in the Hedysarum gmelinii that grows on the southern border of the range in the forest-steppe zone in $\mathrm{SO}$ and OrO regions.

\section{CONCLUSIONS}

Ontogenetic (age) spectra of Pleistocene relictum Hedysarum gmelinii cenopopulations of the European part of the 
range were determined in the study. Seven CPs of the Middle Volga and Cis-Ural regions were characterised by relatively high density $\left(10.0-13.6\right.$ ind. $\left./ \mathrm{m}^{2}\right)$. Ontogenetic spectrum in majority of CP was incomplete-membered, which was associated with a high plant mortality rate after completion of the generative state, and also because $H$. gmelinii grows at communities with a quite dense herb layer that hinders seed germination and young plant development. Seeds are often washed off by rainfall or blown away by wind from the substrate surface in the case when species grows on chalk downs in communities with a sparse herb layer, and newly formed seedlings perish due to significant moisture deficiency. Young plants are severely affected by erosion processes on hill slopes.

According to the "delta-omega" classification, H. gmelinii CPs in the Bashkir Cis-Urals are predominantly young, less often mature. H. gmelinii, as a species is represented by fairly well preserved and numerous populations and does not require additional conservation measures in this area; therefore, its exclusion from the number of protected species in the RB territory is justifiable. However, the state of this species' populations in Bashkortostan requires further monitoring considering their low numbers and because the species is located on an isolated fragment, which occupies only a few administrative districts of the central part of the Pre-Ural, removed from the main range.

The majority of populations in Samara and Orenburg Oblast are mature. The number of known habitats is small there, and the number of individuals in them (with rare exceptions) is insignificant. In these regions, we consider inclusion of this representative in the Red Book as well as further monitoring to be appropriate and necessary, as populations tend to age and decrease in numbers with an increase in anthropogenic press.

Altai CPs have significant similarities in the composition of ontogenetic groups in their spectra. The allocation of local peaks of spectra is often formal; ontogenetic groups occupy approximately equal positions. Most of the CPs belong to the maturing type, one of them is transitional. The ontogenetic spectra of the region's CPs do not differ significantly depending on intensity of the anthropogenic press, but density (and number) of individuals in a CP depends on the degree of pascual load.

Thus, boundary populations of $H$. gmelinii in the Middle Volga and Cis-Urals regions are more diverse in types of ontogenetic spectra, which is an adaptation feature that contributes to conservation of the species in an isolated part of the range in the European part of Russia.

\section{ACKNOWLEDGEMENTS}

This research project was financially supported by the Programme of RAS Presidium, "Biodiversity of Natural Systems and Biological Resources of Russia" and within the framework of the state assignments of SUBGI UFRC
(South-Ural Botanical Garden-Institute of Ufa Federal Research Centre) of RAS and Samara State University of Social Sciences and Education.

\section{REFERENCES}

Abramova, L. M., Ilyina, V. N., Karimova, O. A., Mustafina, A. N. (2016). Comparative analysis of population pattern of Hedysarum grandiflorum (Fabaceae) in Samara region and Republic of Bashkortostan [Абрамова, Л. М., Ильина, В. Н., Каримова, О. А., Мустафина, А. Н. Сравнительный анализ структуры популяций Hedysarum grandiflorum (Fabaceae) в Самарской области и Республике Башкортостан]. Plant resources [Растительные ресурсы], 52 (2), 225-239 (in Russian).

Abramova, L. M., Ilyina, V. N., Mustafina, A. N., Karimova, O. A. (2019). Features of the organization of populations of a rare species Cephalaria uralensis (Murr.) Schrad. ex Roem. et Schult. (Dipsacaceae, Magnoliópsida) in the Trans-Volga and Cis-Urals Regions. Biol. Bull., 46 (10), 1199-1205.

Abramova, L. M., Karimova, O. A., Andreeva, I. Z. (2010). Structure and state of Althaea officinalis (Malvaceae) cenopopulations in the South Cis-Urals (the Republic of Bashkortostan) [Абрамова, Л. М., Каримова, О. А., Андреева, И. 3. Структура и состояние ценопопуляций Althaea officinalis (Malvaceae) на юге Предуралья (Республики Башкортостан)]. Plant resources [Pacmuтельные ресурсы], 46 (4), 46-53 (in Russian).

Abramova, L. M., Karimova, O. A., Mustafina, A. N. (2014). Characteristic of cenopopulations of a rare species Hedysarum grandiflorum Pall. in stony steppes of the Cis-Ural. Italian Sci. Rev., 2 (11), 241-244.

Abramova, L. M., Mustafina, A. N., Andreeva, I. Z. (2011). Modern state and structure of natural populations of Dictamnus gymnostylis Stev. in the South Urals [Абрамова, Л. М., Мустафина, А. Н., Андреева, И. 3. Современное состояние и структура природных популяций Dictamnus gymnostylis Stev. на Южном Урале]. Bull. Moscow Soc. Naturalists, Biol. Ser. [Бюлл. МОИП. Отд. биол.], 116 (5), 32-38 (in Russian).

Abramova, L. M., Mustafina, A. N., Karimova, O. A., Golovanov, Ya. M., Shigapov, Z. H. (2019). Structure and state of populations of three rare species of Hedysarum (Fabaceae) genus in the South Urals [Абрамова, Л. М., Мустафина, А. Н., Каримова, О. А., Голованов, Я. М., Шигапов, 3. Х. Структура и состояние популяций трех редких видов рода Hedysarum (Fabaceae) на Южном Урале]. Bot. J. [Ботанический журнал], 104 (5), 729-740 (in Russian).

Anonymous (1976). Plant Cenopopulations (Main Concepts and Structure [Ценопопуляции растений (основные понятия и структура)]. Moscow. 217 pp. (in Russian).

Anonymous (2004 (2005)). Red List of Rare and Endangered Animal and Plant Species. Part 3.1 (Seed Plants) [Красный список особо охраняемых редких и находящихся под угрозой исчезновения животных и растений. Ч. 3.1 (Семенные растения)]. Moscow. 352 pp. (in Russian).

Anonymous (2011). Red Book of the Republic of Bashkortostan. Plants and Fungi [Красная книга Республики Башкортостан. T.1. Растения и грибыл]. Vol. 1. MediaPrint, Ufa. 384 pp. (in Russian).

Anonymous (2016). Red Book of the Republic of Tatarstan: Animals, Plants, Fungi. [Красная книга Республики Татарстан: животные, растения, грибы]. Nazirov, A. A. (Ed.). 3rd edn. Ideal-press, Kazan. 760 pp. (in Russian).

Anonymous (2017b). Red Book of the Samara Oblast. Rare Species of Plants and Fungi [Красная книга Самарской области. T. I. Редкие виды растений и грибов]. Vol. 1. Senator, S. A., Saksonov, S. V. (eds.). 2nd edn., revised and updated. Samara. 384 pp. (in Russian).

Anonymous (2017a). Red Book of the Chelyabinsk Oblast: Animals, Plants, Fungi [Красная книга Челябинской области: Животные, растения, грибы]. Lagunov, A. V. (Ed.). 2nd edn. Reart Publ., Moscow. 504 pp. (in Russian). 
Basargin, E. A. (2007). Ecological-demographic characterization of Potentilla bifurca cenopopulations. Russ. J. Ecol., 38 (5), 323-326.

Dahlgren, J. P., Roach, D. A. (2017). Demographic senescence in herbaceous plants. In: The Evolution of Senescence in the Tree of Life. Cambridge University Press, pp. 303-319.

Edelfeldt, S., Dahlgren, J. P., Bengtsson, K. (2019). Demographic senescence and effects on population dynamics of a perennial plant. Ecology. 100 (8), 27-42.

Fardeeva, M. B., Chizhikova, N. A., Biryuchevskaya, N. V., Rogova, T. V., Saveliev, A. A. (2009). Mathematical approaches to the space-age structure analysis of turf grass species populations [Фардеева, М. Б., Чижикова, Н. А., Бирючевская, Н. В., Рогова, Т. В., Савельев, А. А. Математические подходы к анализу пространственно-возрастной структуры популяций дерновинных видов трав]. Ecology [Экология], No. 4, 249-257 (in Russian).

Garnier, E., Fayolle, A., Leurent, C., Violle, C., Navas, M. L., Richarte, J., Damgaard, C., Cruz, P., Hubert, D., Autran, P. (2018). Plant demographic and functional responses to management intensification: A long-term study in a mediterranean rangeland. $J$. Ecol., 106 (4), 1363-1376.

Glotov, N. V. (1998). On the estimation of the parameters of the age structure of plant populations [Глотов, Н. В. Об оценке параметров возрастной структуры популяций растений]. In: Life of Populations in Heterogeneous Environment [В кн.: Жизнь популяиий в гетерогенной среде], Part 1, Yoshkar-Ola, 146-149.

Harper, J. L. (1960). Factors controlling plant numbers. In: Harper, J. L. (Ed.). The Biology of Weeds. Oxford, pp. 119-132.

Harper, J. L. (1970). The population biology of plants. In: Harper, J. L. (Ed.). Population Control. Harmondsworth, pp. 32-44.

Harper, J. L., White, J. (1974). The demography of plants. Annual Rev. Ecol. Syst., 5, 419-463.

Harper, J. L. (1977). Population Biology of Plants. Academic Press, London. $892 \mathrm{pp}$.

Ilyina, V. N. (2006). Ecological and biological features and structure of cenopopulations of rare species of the genus Hedysarum L. in the conditions of the Middle Volga basin [Ильина, В. Н. Эколого-биологические особенности и структура ценопопуляций редких видов рода Hedysarum L. в условиях бассейна Средней Волги]: Abstract of Diss. Cand. Sci. (Biology). Institute of Ecology of the Volga basin, RAS, Tolyatti. 19 pp. (in Russian)

Ilyina, V. N. (2007). Structure of populations of Hedysarum gmelinii Ledeb. on the western boundary and in the central part of the area [Ильина, В. Н. Структура популяций Hedysarum gmelinii Ledeb. на западной границе и в центральной части ареала]. Proc. Samara Sci. Centre, RAS [Известия Самарского НЦ РАН], 9 (1), 153-157 (in Russian).

Ilyina, V. N. (2011). Ontogenesis of the Hedysarum gmelinii Ledeb. [Ильина, В. Н. Онтогенез копеечника Гмелина (Hedysarum gmelinii Ledeb.)]. In: Ontogenetic Atlas of Medicinal Plants [Онтогенетический атлас растений: научное издание]. Vol. 6. MarSU, Yoshkar-Ola, pp. 102-107 (in Russian).

Ilyina, V. N. (2019). Rare Hedysarum on the Middle Volga. Biology, Population Structure, and Protection Issues [Ильина, В. Н. Редкие копеечники на Средней Волге. Биология, структура популяций и вопросы охраны: монография]. Samara State University of Social Sciences and Education, Samara. 164 pp. (in Russian).

Karimova, O. A., Abramova, L. M., Golovanov, Y. M. (2017). Analysis of the current status of populations of rare plant species of nature monument Troicki Chalk Mountains (Orenburg region). Arid Ecosystems, 7 (1), $41-48$.

Karnaukhova, N. A., Syeva, S. Ya. (2017). Hedysarum of Southern Siberia [Карнаухова, Н. А., Сыева, С. Я. Копеечники Южной Сибири]. Koncept, Barnaul. 501 pp. (in Russian).
Knyazev, M. S. (2014). Legumes (Fabaceae Lindl.) of the Urals: origin of species, geographical distribution, historically-ecological groups [Князев M. C. Бобовые (Fabaceae Lindl.) Урала: видообразование, географическое распространение, историко-экологические свиты]: Diss. Doct. Biol. Sci. Komarov Botanical Institute, RAS, St. Petersburg. 607 pp. (in Russian).

Kucherov, E. V., Muldashev, A. A., Galeva, A. Kh. (2001). Red Book of the Republic of Bashkortostan. Rare and endangered higher vascular plants [Кучеров, Е. В., Мулдашев, А. А., Галеева, А. Х. Красная книга Республики Башкортостан. T.1. Редкие и исчезающие виды высших сосудистых растений]. Vol. 1. Kitap, Ufa. 280 pp. (in Russian).

Lugovaya, D. L., Smirnova, O. V., Zaprudina, M. V., Aleynikov, A. A., Smirnov, V. E. (2013). Micromosaic structure and phytomass of ground vegetation in main types of dark conifer forests in the Pechora-Ilych state nature reserve. Russ. J. Ecol., 44 (1), 1-8.

McCune, B., Grace, J. B. (2002). Analysis of Ecological Communities. Gleneden Beach, Oregon: MiM Sofware Design. 300 pp.

Naumova, L. G., Zlobin, Yu, A. (2009). Fundamentals of Plant Population Ecology [Наумова, Л. Г., Злобин, Ю. А. Основы популяционной экологии растений]. Bashkir State Pedagogical University Publ., Ufa, 88 pp. (in Russian).

Oldfather, M. F., Ackerly, D. D. (2019). Microclimate and demography interact to shape stable population dynamics across the range of an alpine plant. New Phytologist, 222 (1), 193-205.

Osmanova, G. O. (2008). Morphological features of shoots in Plantago arenaria Waldst. et Kit. (Plantaginaceae L.) under different ecological conditions. Biol. Bull., 35 (5), 541-544.

Osmanova, G. O. (2016). Biomorphology of Actea erythrocarpa Fisch. individuals and ecological-demographic characterization of its cenopopulations. Biol. Bull., 43 (5), 468-473.

Osmanova, G. O., Zhivotovsky, L. A. (2020). The ontogenetic spectrum as an indicator of the status of plant population. Biol. Bull., 47 (2). 141-148.

Rabotnov, T. A. (1950). Life cycle of perennial herbaceous plants in meadow cenoses [Работнов, Т. А. Жизненный цикл многолетних травянистых растений в луговых ценозах]. Tr. BIN AN SSSR [Proc. Bot. Inst., USSR Acad. Sci.]. Series 3. Geobotany. Issue 6. Moscow-Leningrad, pp. 7-204 (in Russian).

Rodriguez-Riaio, T., Ortega-Olivencia, A., Devesa, J. A. (2004). Reproductive biology in Cytisus multiflorus (Fabaceae). Ann. Bot. Fenn., 41 (3), 179-188.

Rysin, L. P., Kazantseva, T. N. (1975). Method of cenopopulational analysis in the geobotanical investigations [Рысин, Л. П., Казанцева, Т. Н. Метод ценопопуляционного анализа в геоботанических исследованиях]. Bot. J. [Бот. журн.], 60 (2), 199-209 (in Russian).

Schemske, D. W. (1985). Plant populations. Perspectives on plant population ecology. Science, 227 (4685), 405-406.

Smirnova, O. V., Geraskina, A. P. (2019). Current Northern Eurasia forest condition: Methods of analysis and restoration of natural biota in protected areas. Literature review end recommendations for required research in protected areas. Russ. J. Ecosyst. Ecol., 4 (1), 1-12.

Smirnova, O. V., Palenova, M. M., Komarov, A. S. (2002). Ontogeny of different life forms of plant and specific features of age and spatial structure of their populations. Russ. J. Devel. Biol., 33 (1), 1-10.

Smirnova, O. V., Zaugolnova, L. B., Istomina, I. I., Khanina, L. G. (2000). Population mosaic cycles in forest ecosystems. In: Vegetation Science in Retrospect and Perspective. Proceedings of the 41st Symposium of International Association of Vegetation Science. Opulus, Uppsala, pp.108-112.

Sterk, A. A. (1975). Demographic studies of Anthyllis vulneraria L. in the Netherlands. Acta Bot. Neerland., 24, 315-337.

Syeva, S. Ya., Karnaukhova, N. A. (2019). The biological potential of cenopopulations of Hedysarum gmelinii Ledeb. (Fabaceae) in the Altai 
Mountains [Сыева, С. Я., Карнаухова, Н. А. Биологический потенциал ценопопуляций Hedysarum gmelinii Ledeb. (Fabaceae) в Горном Алтае]. In: Major Problems of Mountain Agriculture. Proceedings of the VII International Research-to-Practice Conference dedicated to the 70th anniversary of the Gorno-Altaisk State University. Gorno-Altaysk, pp. 404-411 (in Russian).

Uranov, A. A. (1975). Age spectrum of phytocenopopulations as a function of time and energy wave processes [Уранов, А. А. Возрастной спектр фитоценопопуляции как функция времени и энергетических волновых процессов]. Biol. Sci. [Биологические науки], 2, 7-34 (in Russian).

Uranov, A. A., Smirnova, O. V. (1969). Classification and main features of the development of perennial plant populations [Уранов, А. А., Смирнова, О. В. Классификация и основные черты развития популяций многолетних растений]. Bull. Moscow Soc. Natur. Biol. Ser. [Бюлл. МОИП. Отд. биол.], 79 (1), 119-135 (in Russian).

Vaz, A. S., Alves, P., Vicente, J. R., Caldas, F. B., Honrado, J. P., Lomba, A., Silva, D. (2016). Evaluating populations and community structure against climate and land-use determinants to improve the conservations of the rare Narcissus pseudonarcissus subsp. nobilis. Annales del Jardin Botanico de Madrid, 73 (1), e027.

Villellas, J., Garcia, M. B., Morris, W. F. (2013). Variation in stochastic demography between and within central and peripheral regions in a widespread short-lived herb. Ecology, 94 (6), 1378-1388.

Received 22 January 2020

Accepted in the final form 9 October 2020
Zaitsev, G. N. (1990). Mathematics in Experimental Biology [Зайцев, Г. H. Математика в экспериментальной биологии]. Nauka, Moscow. 296 pp. (in Russian).

Zaugolnova, L. B., Smirnova, O. V. (1978). Age structure of cenopopulations of perennial plants and its dynamics [Заугольнова, Л. Б., Смирнова, О. В. Возрастная структура ценопопуляций многолетних растений и ее динамика]. Zhurnal Obshchei Biologii [Журн. общ. биологии], 39 (6), 849-857 (in Russian).

Zhivotovsky, L. A. (2001). Ontogenetic states, effective density, and classification of plant populations [Животовский, Л. А. Онтогенетические состояния, эффективная плотность и классификация популяций растений]. Ecology [Экология], 1, 3-7.

Zhmud, E. V. (2014). Ecological flexibility of Hedysarum gmelinii Ledeb. (Fabaceae) in Altai mountains and Khakassia [Жмудь Е. В. Экологическая пластичность Hedysarum gmelinii Ledeb. (Fabaceae) в Горном Алтае и Хакасии]. Tomsk State Pedagogical University Bulletin [Вестник ТГПУ], 11 (152), 220-226 (in Russian).

Zhukova, L. A. (1995). Population Life of Meadow Plants [Жукова, Л. А Популяционная жизнь луговых растений]. Lanar, Yoshkar-Ola. 224 pp. (in Russian).

Zhukova, L. A. (2001). Diversity of ontogenic pathways in plant populations. Russ. J. Ecol., 32 (30), 151-158.

Zlobin, Yu. A., Sklyar, V. G., Klimenko, A. A. (2013). Populations of Rare Plant Species: Theoretical Foundations and Methodology of the Study [Злобин, Ю. А., Скляр, В. Г., Клименко, А. А. Популяции редких видов растений: теоретические основы и методика изучения]. Universitetskaya Kniga, Sumi. 439 pp. (in Russian).

\section{RETĀ RELIKTA HEDYSARUM GMELINII LEDEB. (FABACEAE) DEMOGRĀFISKĀS STRUKTŪRAS ĪPATNĪBAS UN POPULĀCIJU STĀVOKLIS TĀ IZPLATİBAS PERIFĒRĀ UN CENTRĀLĀ DAL̄Ā}

Pētītas Hedysarum gmelinii Ledeb. (Fabaceae) populācijas sugas izplatības perifērijāa (vidus Volga un Baškīrijas Urāli) un centrālajā daḷā (Altaja kalni), noteikti faktori kas ietekmē cenopopulāciju vecuma spektru. 